\title{
Cost estimating of company's good standing with consideration of correspondence of real estate objects to the «green building» standard
}

\author{
Angelina Gorobnyak ${ }^{1, *}$ \\ ${ }^{1}$ Moscow State University of Civil Engineering,26, Yaroslavskoye shosse, Moscow,129337, Russia
}

\begin{abstract}
Article presents method of assessment of the value of the construction company's goodwill based on the analysis of the current value of the company shares and value of its depositary receipts. Here analyzed main principles of the "green" building and problems of increasing of the levels of the construction company's goodwill for assessment of which system of indicators, considering current trends and correspondence of the real estate objects to the standards of the "green" building was developed. The result of approbation of this method is calculation of cost of the business reputation of the large international construction-development company.
\end{abstract}

\section{Introduction}

Issues of assessment of the value of goodwill are particularly topical now, because capitalization of many companies, whose shares are traded on the stock exchange, is much higher than the value of all its assets. Significant role in company market-value formation has its goodwill on the market. Issues which previously were not considered a priority ones have great importance for construction companies at this time. The question is about compliance of real estate objects to the international standards of "green" building which are under commissioning. The more investors and users of the real estate items give special attention to whether one or another construction company supports ideas of preservation and the ethic relation to natural resources and for improvement of energy efficiency in buildings. Certainly, this fact exerts ever increasing impact on the formation of positive or negative goodwill of construction companies. So there exists a necessity to develop the system indicators for assessment of the level of goodwill of the construction companies which considers tendencies of development and green standards of the building and value assessment of goodwill, which presented in this article.

\section{Methods}

Goodwill of the company is invisible asset which has its value[1]. However, it's quite complex task to assess this value in practice.

*Corresponding author: kovalskayaangelina@yandex.ru 
Goodwill has following characteristics:

- this is intangible asset of the company;

- has a certain value;

- has no physical content;

- brings incomes or creates circumstances for income generation for the company;

- being used for a long period (the entire period of the existence of the company).

There are three components of reputation management:

- crisis management;

- risk management;

- social accountability.

Value of the goodwill can be presented as difference between shares of the company and the value of its depositary receipts.

Depositary receipt is secondary securities which freely turn on the stock market and issued in the form of certificate by the depositary bank of world importance for shares of international cash and that certifies about possession of a certain number of shares of a foreign company, deposited in the location country of this company, circulation of which is performing in another one.

American depositary receipts (ADR) and global depository receipts (GDR) are used in the world practice.

There are also Russian Depository Receipts (RDR). These registered issuance securities which have following characteristics:

- havenonotionalvalue;

- certify property on a certain number of shares or international cash bonds;

- establish the right of their owner to demand from RDR issuer the corresponding quantity of submitted securities and services related to the implementation of the rights enshrined by the presented securities by the owner of RDR;

- can be sponsored or not sponsored.

Sponsored RDR appear in case when issuer of the presented securities (PCB) accepts obligations on securities and state registration of issue is performed by the regulator.

Not sponsored RDR appear in case when issuer of the underlying securities (PCB) doesn't assume obligations on securities and identification number, which is assigned by exchange or regulator.

Main purposes of the depositary receipts issue for the companies are:

- attraction of additional financial resources for implementation of investment projects;

- increase of the market value of stocks as a result of increasing demand on native market;

- attraction of the investors with foreign portfolio;

- increase of the business reputation and image of the company.

Achievement of the last point is possible due to issuing of depositary receipts for company shares by the famous world banks, cooperation with which attracts foreign and native investors. Bank of New York, Citibank and Morgan Stanley are leaders in sphere of the custody services on the world market.

Value of shares of the company at the IPO is usually higher than the cost of its depositary receipts.

As for indexes for assessment of the goodwill level of the company, in the modern conditions of construction industry development its necessary to pay special attention to the "green" building standards.

Considering a problem of the goodwill level of construction companies increase, that, subsequently, will allow to increase its value, there should be noted the tendency to strengthen the influence of "green" construction standards in this area. 
The main principles of green building are:

- Application of construction materials with high levels of energy efficiency and conservation;

- Application of green building materials;

- Usage of renewable energy sources in the process of building;

- Minimum waste and harmful environmental impact;

- Application of building materials of the local origin (with the purpose to reduce pollution of the environment during transport).

There are following "green" building standards:

1. BREEAM Standard (BRE Environmental Assessment Method)- is designed by the British company BRE Global.

2. LEED (LeadershipinEnergyand Environmental Design - Management on ecologic and green design).

3. DGNB (German Association on sustainable development);

4. Russian National Standard 54964-2012 «Compliance assessment. Environmental requirements for real estate units and industry standard of National Association of Builders 2.35.4-2011.

Existence of certificates of the green building standards of the real estate units allows to talk about certain degree of ecological compatibility of these units, that certainly attracts investors and improves the reputation level of the development company.

That's why certificates of LEED and BREEM of the real estate units must be included in the general system of indicators for assessing the level of construction company's goodwill.

\section{Results}

Author formed the system of indicators for assessment of the goodwill of the construction company level, which is presented in the table 1[2].

Table 1.Indicators of assessment of goodwill of the construction company

\begin{tabular}{|c|c|c|c|}
\hline № & Indicator & Indicatorvalue & $\begin{array}{l}\text { Formula/ } \\
\text { Recommen } \\
\text {-ded } \\
\text { Value } \\
\end{array}$ \\
\hline $\mathrm{R}_{1}$ & $\begin{array}{l}\text { SRO permission on the } \\
\text { performance of the necessary } \\
\text { works }\end{array}$ & $\begin{array}{l}\text { Shows the availability of resources and } \\
\text { capability to conduct construction activities }\end{array}$ & Available \\
\hline $\mathrm{R}_{2}$ & $\begin{array}{l}\text { Availability of the LEED, } \\
\text { BREEAM certificates for the } \\
\text { real estate units built by the } \\
\text { company }\end{array}$ & $\begin{array}{l}\text { Shows the degree of ecological } \\
\text { compatibility of real estate units }\end{array}$ & Max \\
\hline $\mathrm{R}_{3}$ & $\begin{array}{l}\text { Availabilityofconstructionacti } \\
\text { vity }\end{array}$ & $\begin{array}{l}\text { Shows the level of protection of the } \\
\text { company from different risks }\end{array}$ & Max \\
\hline $\mathrm{R}_{4}$ & $\begin{array}{l}\text { Experience of the company } \\
\text { on the units similar to the } \\
\text { contract object }\end{array}$ & $\begin{array}{l}\text { Shows the experience of building of the } \\
\text { similar real estate units }\end{array}$ & Max \\
\hline $\mathrm{R}_{5}$ & Opinionofratingagencies & $\begin{array}{l}\text { Considers experience of the rating agencies } \\
\text { and awards picked up by the company }\end{array}$ & $\begin{array}{l}\text { Positivete } \\
\text { ndency }\end{array}$ \\
\hline $\mathrm{R}_{6}$ & $\begin{array}{l}\text { Absence of violations of the } \\
\text { maturities of loans and } \\
\text { interest on loans, mln. rub }\end{array}$ & $\begin{array}{l}\text { Shows the rate of implementation of the } \\
\text { company obligations to creditors }\end{array}$ & $\min$ \\
\hline $\mathrm{R}_{7}$ & $\begin{array}{l}\text { Always high quality of the } \\
\text { construction products, } \\
\text { quantity of the presented }\end{array}$ & $\begin{array}{l}\text { It is characterized by the amount of } \\
\text { presented warranty claims }\end{array}$ & $\min$ \\
\hline
\end{tabular}




\begin{tabular}{|c|c|c|c|}
\hline & warranty claims & & \\
\hline $\mathrm{R}_{8}$ & $\begin{array}{l}\text { High level of the workforce } \\
\text { skill and management } \\
\text { personnel }\end{array}$ & $\begin{array}{l}\text { Number of working employees with: an } \\
\text { MBA degree, Degree level, high core } \\
\text { education, professional education, passed } \\
\text { courses of improvement of qualification }\end{array}$ & Max \\
\hline $\mathrm{R}_{9}$ & $\begin{array}{l}\text { Experience of payments on } \\
\text { the punitive sanctions for } \\
\text { violations of the normative } \\
\text { period of input of a } \\
\text { construction unit in operation }\end{array}$ & $\begin{array}{l}\text { Shows the degree of fulfillment of } \\
\text { obligations on the timely input of units in } \\
\text { operation by the company }\end{array}$ & $\min$ \\
\hline $\begin{array}{l}\mathrm{R}_{1} \\
0\end{array}$ & $\begin{array}{l}\text { Participation in arbitrage } \\
\text { processes as defendant }\end{array}$ & $\begin{array}{l}\text { Participation in the courts for the resolution } \\
\text { of disputes arising out of civil legal } \\
\text { relations or legal relations in the sphere of } \\
\text { management }\end{array}$ & $\min$ \\
\hline $\begin{array}{l}\mathrm{R}_{1} \\
1\end{array}$ & $\begin{array}{l}\text { Mass media publications on } \\
\text { the activities of the company } \\
\text { or its employees }\end{array}$ & $\begin{array}{l}\text { Shows tendencies in changes of public } \\
\text { opinion about the company and its products }\end{array}$ & $\begin{array}{l}\text { Positiveba } \\
\text { ckground }\end{array}$ \\
\hline $\mathrm{R}_{1}$ & $\begin{array}{l}\text { Experience in the } \\
\text { construction of unique units }\end{array}$ & $\begin{array}{l}\text { Shows the experience in the construction of } \\
\text { the unique buildings }\end{array}$ & Max \\
\hline $\mathrm{R}_{1}$ & $\begin{array}{l}\text { Absence of conflict in the } \\
\text { workplace }\end{array}$ & $\begin{array}{l}\text { Shows the level of organizational culture of } \\
\text { the company }\end{array}$ & $\min$ \\
\hline $\begin{array}{l}\mathrm{R}_{1} \\
4\end{array}$ & The level of salary of workers & $\begin{array}{l}\text { Shows the average amount of money } \\
\text { received by employee of the company per } \\
\text { year }\end{array}$ & Max \\
\hline
\end{tabular}

For assessment of goodwill let's consider the difference in value of the shares of the company and its depositary receipts on the example of the Russian real estate development and construction company HALs-development, shares of which are traded on the Moscow stock exchange.

On 01.03.2016 the cost of global depository receipts (GDR) of the company under consideration amounted $\$ 1.1$.

On 01.03.2016, the cost of the ordinary shares of the HALs-development company amounted 1770 rub. per share.

Greatest impact of value of the company shares for the presented on the graph period became from June 22 to July 6, 2015 then the value of ordinary share decreased from 1550 rub. to 1304 rub. This impact was caused by the appeared reporting of the company for the 1 half-year, which reflected 11,8bln. rub. of losses (a year earlier it was $3.5 \mathrm{bln}$. rub.).

Value of the depositary receipt of the "HALs-development" in the period from June, 22 to August, 10 remained unchanged $\$ 1.35$, so, negative news didn't affect the value or securities in this period.

Quantity of depositary receipts is 32370780 on the number of shares, which amounts 11217 094. Thus, on 01.03.2016 value of depository receipts of HALs-development, considering dollar exchange amounted $2 \mathrm{bln} .702 \mathrm{mln}$. 280 thousand $343 \mathrm{rub}$. The value of all shares of the company that day amounted $19 \mathrm{bln} .854 \mathrm{mln} .256$ thousand $380 \mathrm{rub}$.

Thus, the difference between value of depository receipts and shares of the HALsdevelopment amounted more than 17 bln. rub. on March 1, 2016. We can estimate the value of goodwill of the company (fig. 1) at this figure. 


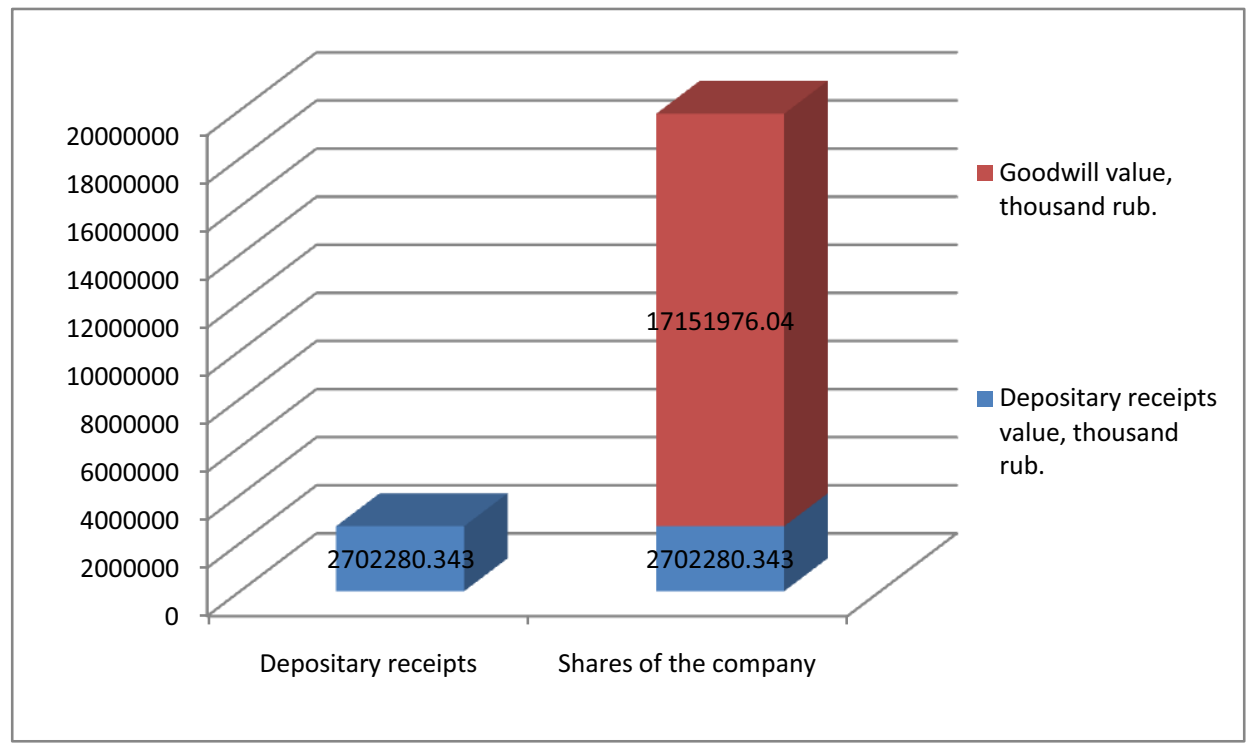

Fig 1. Diagram of structure of value of the "HALs-development" company

\section{Discussion}

Issues on the necessity of goodwill price valuation and necessity of the construction products compliance to the "green" building standards were previously reviewed in scientific works, periodicals and scientific reviews (Larionov A. N.[3, 4, 5], Nezhnikova E. V.[6, 7], etc. [8]).

In their works scientists analyze the indicators for the goodwill assessment and note that priorities are minimization of violations of the normative term of input of a construction unit in operation, experience in punitive sanctions payments, participation in arbitration proceedings and timely payment of loans and interests. However, impact of the conformity of units to the "green" building standards on the value of its reputation wasn't considered in these works previously.

That's why the system of indicators for the goodwill valuation of the construction company must also contain the generally accepted indicators of the real estate unit's conformity to the standards of "green" building in addition to generally accepted ones.

\section{Conclusion}

The proposed system of indicators for assessment of the goodwill level of the construction company takes into consideration not only conventional indicators, but the necessity of conformity of the construction products to the "green" building standards, that corresponds to modern trends in the development of the economy and society as a whole. Nowadays is the real estate unit having international standard BREEAM or LEED, it's an indicator of efficiency, quality and safety, and raises the confidence of investors and consumers.

In turn, goodwill valuation on the basis of analysis of value of shares and depositary receipts allows to calculate how many goodwill costs, that was amply demonstrated in the 
article on the example of the calculation of the goodwill value of the Russian construction and development company HALs-development.

\section{References}

1. A. Gorobnyak A. A. Economy and Entrepreneurship, 8, 618-622, (2014)

2. A. Gorobnyak. Economy and Entrepreneurship, 4 (2), 529-532, (2016)

3. A. Larionov. Journal of legal and economic studies, 3, 234-238, (2014)

4. A. Larionov, E. Nezhnikova. International Journal of Applied Engineering Research, 6 (11), 4433-4439, (2016)

5. A. Larionov, E. Nezhnikova. ARPN Journal of Engineering and Applied Sciences, 3 (11), 2023-2029,(2016)

6. E. Nezhnikova. SWorldJournal, 2, 14-17, (2015)

7. E. Nezhnikova. Economy and Entrepreneurship, 6, 30-35,(2015)

8. L. Cabral. Research in Economics, 70 (4), 735-740, (2016) 